\title{
HUBUNGAN TINGKAT KEPATUHAN MINUM OBAT DENGAN TEKANAN DARAH PADA PASIEN HIPERTENSI DI KELOMPOK PENGELOLAAN PENYAKIT KRONIS (PROLANIS) KLINIK QITA
}

\author{
Ferry Effendi $^{1 *}$, Elis Tiahesara ${ }^{2}$, Debi Rizki Azana $^{3}$ \\ 1. Program Studi S1 Farmasi, Sekolah Tinggi Teknologi Industri dan Farmasi, Bogor \\ 2. Klinik Qita Bogor \\ 3. Mahasiswa Program Studi S1 Farmasi Sekolah Tinggi Teknologi Industri dan Farmasi, Bogor \\ *Korespondensi: f312ye@gmail.com
}

\begin{abstract}
ABSTRAK
Hipertensi secara luas dikenal dengan penyakit kardiovaskular dimana penderita memiliki tekanan darah di atas tekanan darah normal, tepatnya dimana tekanan darah sistolik $\geq 140 \mathrm{mmHg}$ dan tekanan diastolik $\geq 90 \mathrm{mmHg}$ yang diukur dalam keadaan tenang pada dua kali pengukuran. Kepatuhan minum obat hipertensi memberikan kontribusi besar terhadap kestabilan tekanan darah. Salah satu upaya yang dilakukan untuk meningkatkan kepatuhan minum obat hipertensi yaitu dengan mengikuti program Pengelolaan Penyakit Kronis (Prolanis). Penelitian ini bertujuan untuk mengetahui hubungan tingkat kepatuhan minum obat dengan tekanan darah pada pasien hipertensi di kelompok Pengelolaan Penyakit Kronis (Prolanis) Klinik Qita. Penelitian ini menggunakan metode penelitian analitik dengan pendekatan cross-sectional, dalam penelitian ini sampel ditentukan dengan metode purposive. Instrumen penelitian ini adalah kuisioner MMAS-8 (Morisky Medication Adherence Scale-8) dan 1 set alat tensimeter. Dari hasil penelitian menunjukan bahwa responden dengan kepatuhan tinggi sebanyak 14 responden (46.7\%), kepatuhan sedang sebanyak 5 responden (15.7\%) dan kepatuhan rendah sebanyak 11 responden (36.7\%). Hasil pengujian korelasi pada penelitian ini menunjukkan adanya hubungan kepatuhan minum obat dengan tekanan darah sistolik dengan $p<0,05$ dengan nilai signifikansi 0,038 dan terdapat hubungan dengan tekanan darah diastolik dengan $p<0,05$ dengan nilai signifikansi 0,024 .
\end{abstract}

Kata kunci: hipertensi, kepatuhan minum obat, Prolanis

\begin{abstract}
Hypertension is widely known for its cardiovascular disease in which sufferers have blood pressure above normal blood pressure, precisely where systolic blood pressure $\geq 140 \mathrm{mmHg}$ and diastolic pressure $\geq 90 \mathrm{mmHg}$ measured in calm at two measurements. Compliance to medication of hypertension contributes greatly to the stability of the blood pressure. One of the efforts made to improve compliance with medication of hypertension with the chronic disease management program (Prolanis). This research aims to know the relationship of the level of compliance of taking the drug with blood pressure in patients of hypertension in chronic disease management group (Prolanis) Qita Clinic. This research use analytic research method to approach crosssectional, in the study sample is determined by the method of purposive. This research instrument is the questionnaire MMAS-8 (Morisky Medication Adherence Scale-8) and 1 set of tools tensimeter. From the results of the research showed that respondents with high compliance as much as 14 respondents $(46.7 \%)$, compliance are as many as 5 respondents $(15.7 \%)$ and low compliance as much as 11 respondents $(36.7 \%)$. Correlation of test results of these studies showed a relationship with medication compliance systolic blood pressure with a $\mathrm{p}$ value of 0.05 signifies < 0.038 and there is a connection with diastolic blood pressure with a $\mathrm{p}$ value of 0.05 signifies < 0.024 .
\end{abstract}

Keywords: hypertension, medication compliance, prolanis 


\section{PENDAHULUAN}

Menurut data Riskesdas (2013) prevalensi hipertensi penduduk indonesia umur $\geq 18$ tahun sebesar 26,5\%. Sebesar 36,8\% kasus yang terdiagnosis oleh tenaga kesehatan, sisanya sebesar 63,2\% kasus hipertensi di masyarakat tidak terdiagnosis oleh tenaga kesehatan. Prevalensi hipertensi di Jawa Barat secara regional menempati peringkat ke empat dengan penderita hipertensi tertinggi di Indonesia yaitu sebesar $29,4 \%$.

Ketidakpatuhan pasien hipertensi terhadap pengobatan antihipertensi yang direkomendasikan oleh tenaga kesehatan masih menjadi sebuah masalah global. Edukasi tentang kepatuhan menjalani terapi antihipertensi adalah tantangan utama untuk mengurangi morbiditas dan mortalitas penyakit kardiovaskular [1].

Salah satu upaya yang dilakukan untuk meningkatkan kepatuhan minum obat hipertensi yaitu dengan mengikuti program Pengelolaan Penyakit Kronis (Prolanis). Prolanis atau pengelolaan penyakit kronis merupakan pelayanan kesehatan yang dilakukan dalam rangka pemeliharaan kesehatan bagi peserta BPJS Kesehatan yang menderita penyakit kronis untuk mencapai kualitas hidup yang optimal dengan biaya yang efektif dan efisien.

Ada beberapa aktifitas yang dilakukan Prolanis yaitu diantaranya, konsultasi medis dengan jadwal yang disepakati bersama, edukasi kelompok peserta prolanis yang dilakukan untuk meningkatkan pengetahuan kesehatan dalam upaya memulihkan penyakit, reminder melalui SMS Gateway yang bertujuan untuk memotivasi peserta untuk melakukan kunjungan rutin, dan yang terakhir adalah homevisite [2].

Meskipun telah banyak upaya yang dilakukan masih banyak diantara pasien yang tidak patuh meminum obat secara rutin. Dari sinilah peneliti tertarik melakukan penelitian tentang tingkat kepatuhan minum obat dengan tekanan darah di kelompok pengelolaan penyakit kronis dan dengan penelitian ini diharapkan dapat memberikan informasi yang cukup akurat untuk menangani pasien hipertensi.

\section{METODE PENELITIAN}

Metode yang digunakan dalam penelitian ini adalah metode penelitian analitik dengan pendekatan cross-sectional, dalam penelitian ini sampel ditentukan dengan metode purposive.
Sampel yang dipilih yaitu berdasarkan kriteria inklusi sesuai data yang dibutuhkan dalam penelitian. Penelitian ini dilakukan untuk mendapatkan hubungan antara 2 variabel yaitu hubungan antara kepatuhan minum obat dengan tekanan darah terkendali di Kelompok Pengelolaan Penyakit Kronis (Prolanis) Klinik Qita.

Sampel pada penelitian ini adalah pasien yang sedang menjalani terapi pengobatan hipertensi Kelompok Pengelolaan Penyakit Kronis (Prolanis) di Klinik Qita Kabupaten Bogor. Pengambilan sampel dalam penelitian ini secara purposive sampling, sampel yang diambil berdasarkan ciri-ciri atau sifat yang masuk dalam kriteria inklusi dan eksklusi sebagai sampel sebanyak 30 orang.

Kriteria Inklusi dalam penelitian ini adalah pasien yang terdaftar sebagai anggota kelompok pengelolaan penyakit kronis (Prolanis) Klinik Qita, bersedia menjadi responden dan kooperatif dan pasien hipertensi tanpa penyakit penyerta atau tanpa komplikasi. Kriteria eksklusinya adalah pasien yang pindah fasilitas kesehatan tingkat I, dan pasien yang tidak aktif menjalani kegiatan prolanis. Data penelitian dikumpulkan dari bulan April-Juli 2018.

Pengumpulan data yang digunakan adalah data primer, yaitu data yang didapatkan secara langsung dari subjek penelitian. Instrumen yang digunakan dalam penelitian ini adalah jenis kuesioner, yaitu MMAS-8 (Morisky Medication Adherence Scale-8) dan satu set alat pengukur tekanan darah, yaitu stetoskop dan tensimeter air raksa.

Uji pendahuluan untuk menentukan validitas dan reliabilitas kuesioner dilakukan pada 30 pasien. Semua pertanyaan pada kuesioner dinyatakan valid dengan nilai $r$ hitung semua pertanyaan lebih besar dari nilai $r$ table $(0,361)$, sedangakan nilai Cronbach alpha kuesioner adalah 0,763 yang mengindikasikan bahwa kuesioner yang digunakan pada penelitian ini sudah reliabel. Data yang diperoleh diproses dengan SPSS versi 17. Analisis Data dianalisis dengan menggunakan analisis univariat dan bivariat.

\section{HASIL DAN PEMBAHASAN \\ Analisis Univariat}

Analisis univariat bertujuan untuk mengetahui sebaran dan frekuensi dari variabel-variabel yang hendak diteliti dalam mencari hubungan antara kepatuhan minum obat dengan tekanan darah. 
92 Ferry Effendi et al. (Hubungan Tingkat Kepatuhan Minum Obat...)

Tabel 1. Distribusi Frekuensi Tingkat Kepatuhan Minum Obat Berdasarkan Jenis Kelamin

Variabel

Kepatuhan

(Jenis Kelamin)

Tinggi Sedang

$\mathrm{N} \quad \% \quad \mathrm{~N}$

\begin{tabular}{lcccccccc}
\hline & $\mathrm{N}$ & $\%$ & $\mathrm{~N}$ & $\%$ & $\mathrm{~N}$ & $\%$ & $\mathrm{~N}$ & $\%$ \\
\hline Laki-Laki & 5 & 35.7 & 2 & 40 & 3 & 27.3 & 10 & 33.3 \\
Perempuan & 9 & 64.3 & 3 & 60 & 8 & 72.7 & 20 & 66.7 \\
Total & 14 & 100 & 5 & 100 & 11 & 100 & 30 & 100 \\
\hline
\end{tabular}

Berdasarkan data tersebut didapatkan hasil bahwa kepatuhan minum obat perempuan lebih tinggi daripada laki-laki. Terdapat $64.3 \%$ jenis kelamin perempuan dengan kepatuhan minum obat tinggi. Hal ini sejalan dengan penelitian yang dilakukan Dudella dkk (2012) yang

mengatakan bahwa wanita lebih peka terhadap pengobatan dibandingkan laki-laki dan mereka lebih tekun minum obat karena mereka beranggapan bahwa penyakit mereka kronis yang memerlukan pengobatan terus menerus [3].

Tabel 2. Distribusi Frekuensi Tingkat Kepatuhan Minum Obat Berdasarkan Usia Variabel Kepatuhan

\begin{tabular}{lcccccccc}
\multirow{2}{*}{ (Usia) } & \multicolumn{2}{c}{ Tinggi } & \multicolumn{2}{c}{ Sedang } & \multicolumn{2}{c}{ Rendah } & \multicolumn{2}{c}{ Total } \\
\cline { 2 - 6 } & $\mathrm{N}$ & $\%$ & $\mathrm{~N}$ & $\%$ & $\mathrm{~N}$ & $\%$ & $\mathrm{~N}$ & $\%$ \\
\hline Dewasa Akhir & 2 & 14.3 & 0 & 0 & 0 & 0 & 2 & 6.7 \\
Lansia Awal & 3 & 21.4 & 1 & 20.0 & 3 & 27.3 & 7 & 23.3 \\
Lansia Akhir & 4 & 28.6 & 4 & 80.0 & 4 & 36.4 & 12 & 40.0 \\
Manula & 5 & 35.7 & 0 & 0 & 4 & 36.4 & 9 & 30.0 \\
\hline Total & 14 & 100 & 5 & 100 & 11 & 100 & 30 & 100
\end{tabular}

Berdasarkan usia, kelompok usia manula memiliki kepatuhan tinggi. Terdapat $35.7 \%$ kelompok usia manula dengan tingkat kepatuhan minum obat tinggi. Hal ini tidak sejalan dengan penelitian yang dilakukan oleh Kanda (2014) dimana dalam hasil penelitiannya Kanda menemukan kelompok usia manula memiliki tingkat kepatuhan yang rendah. Umumnya pasien hipertensi dengan usia yang sudah lanjut ditambah lagi sudah lamanya menderita hipertensi mengakibatkan lupa dan enggan meminum obatnya, hal itu disebabkan sudah jenuh meminum obat karena sudah lama diderita tetapi penyakitnya tidak kunjung sembuh [4]. 
93 Ferry Effendi et al. (Hubungan Tingkat Kepatuhan Minum Obat...)

Tabel 3. Distribusi Frekuensi Tingkat Kepatuhan Minum Obat Berdasarkan Tingkat Pendidikan

\begin{tabular}{|c|c|c|c|c|c|c|c|c|}
\hline \multirow{3}{*}{$\begin{array}{c}\text { Variabel } \\
\text { (Tingkat Pendidikan) }\end{array}$} & \multicolumn{6}{|c|}{ Kepatuhan } & & \\
\hline & \multicolumn{2}{|c|}{ Tinggi } & \multicolumn{2}{|c|}{ Sedang } & \multicolumn{2}{|c|}{ Rendah } & \multicolumn{2}{|c|}{ Total } \\
\hline & $\mathrm{N}$ & $\%$ & $\mathrm{~N}$ & $\%$ & $\mathrm{~N}$ & $\%$ & $\mathrm{~N}$ & $\%$ \\
\hline SD & 1 & 7.1 & 1 & 20.0 & 2 & 18.2 & 4 & 13.3 \\
\hline SMP & 1 & 7.1 & 0 & 0 & 2 & 18.2 & 3 & 10.0 \\
\hline SMA & 7 & 50.0 & 3 & 60.0 & 5 & 45.5 & 15 & 50.0 \\
\hline D3 & 2 & 14.3 & 0 & 0 & 1 & 9.1 & 3 & 10.0 \\
\hline $\mathrm{S} 1$ & 2 & 14.3 & 0 & 0 & 1 & 9.1 & 3 & 10.0 \\
\hline $\mathrm{S} 2$ & 1 & 7.1 & 1 & 20.0 & 0 & 0 & 2 & 6.7 \\
\hline Total & 14 & 100 & 5 & 100 & 11 & 100 & 30 & 100 \\
\hline
\end{tabular}

Tingkat kepatuhan tinggi adalah SMA. Terdapat 50\% tingkat pendidikan SMA dengan kepatuhan minum obat tinggi. Hal ini sejalan dengan pendapat Puspita (2016) yang menyebutkan bahwa pendidikan merupakan faktor yang mempengaruhi pengetahuan seseorang, dimana semakin tinggi tingkat

\section{Analisis Bivariat}

Analisis bivariat digunakan untuk mengetahui hubungan variabel independen (tingkat kepatuhan minum obat) dengan pendidikan atau pengetahuan seseorang maka semakin membutuhkan pusat-pusat pelayanan kesehatan sebagai tempat berobat bagi keluarganya. Semakin tinggi pendidikan maka semakin mudah mereka menerima informasi tentang dunia kesehatan sehingga pengetahuan mereka semakin bertambah.

variabel dependen (pengendalian tekanan darah). Analisa penelitian ini menggunakan uji Korelasi Spearman rho's.

Tabel 4. Hubungan Jenis Kelamin Dengan Tekanan Darah Sistolik

\begin{tabular}{|c|c|c|c|c|c|c|c|c|c|c|}
\hline \multirow{3}{*}{$\begin{array}{c}\text { Variabel } \\
\text { (Jenis Kelamin) }\end{array}$} & \multicolumn{8}{|c|}{ Tekanan Darah Sistolik } & & \\
\hline & \multicolumn{2}{|c|}{$\begin{array}{c}\text { Normal < } \\
120 \mathrm{mmHg}\end{array}$} & \multicolumn{2}{|c|}{$\begin{array}{c}\text { Prehipertensi } \\
(120-139 \\
\mathrm{mmHg})\end{array}$} & \multicolumn{2}{|c|}{$\begin{array}{c}\text { Hipertensi } \\
\text { Tahap } 1(140- \\
159 \mathrm{mmHg})\end{array}$} & \multicolumn{2}{|c|}{$\begin{array}{c}\text { Hipertensi } \\
\text { Tahap } 2 \\
(\geq 160 \mathrm{mmHg})\end{array}$} & \multicolumn{2}{|c|}{ Total } \\
\hline & $\mathrm{N}$ & $\%$ & $\mathrm{~N}$ & $\%$ & $\mathrm{~N}$ & $\%$ & $\mathrm{~N}$ & $\%$ & $\mathrm{~N}$ & $\%$ \\
\hline Laki-laki & 2 & 40.0 & 5 & 38.5 & 2 & 33.3 & 1 & 16.7 & 10 & 33.3 \\
\hline Perempuan & 3 & 60.0 & 8 & 61.5 & 4 & 66.7 & 5 & 83.3 & 20 & 66.7 \\
\hline Total & 5 & 100 & 13 & 100 & 6 & 100 & 6 & 100 & 30 & 100 \\
\hline
\end{tabular}


(2014) dimana dalam penelitiannya peningkatan tekanan darah sistolik lebih lebih banyak berjenis kelamin perempuan [5]. Menurut Singalingging (2011) rata-rata perempuan akan mengalami peningkatan tekanan darah tinggi atau hipertensi setelah menopause yaitu usia diatas 45 tahun. Perempuan yang belum menopause dilindungi oleh hormon estrogen yang berperan dalam meningkatkan kadar High Density Lipoprotein (HDL). Kadar kolesterol LDL (Low Density Lipoprotein) mempengaruhi terjadinya proses aterosklerosis [7].
Dari perhitungan dengan menggunakan uji statistik Pearson Chi Square yang diolah dengan menggunakan SPSS versi 17 didapatkan nilai signifikansi 0.800 yaitu $>0.05$ hal ini menunjukkan bahwa tidak ada hubungan antara jenis kelamin dengan tekanan darah sistolik. Pada penelitian yang dilakukan oleh Novitaningtyas (2014), Novitaningtyas juga tidak menemukan adanya hubungan antara jenis kelamin dengan tekanan darah sistolik [5].

Tabel 5. Hubungan Jenis Kelamin Dengan Tekanan Darah Diastolik

\begin{tabular}{|c|c|c|c|c|c|c|c|c|c|c|}
\hline \multirow{3}{*}{$\begin{array}{c}\text { Variabel } \\
\text { (Jenis Kelamin) }\end{array}$} & \multicolumn{8}{|c|}{ Tekanan Darah Diastolik } & & \\
\hline & \multicolumn{2}{|c|}{$\begin{array}{l}\text { Normal < } \\
80 \mathrm{mmHg}\end{array}$} & \multicolumn{2}{|c|}{$\begin{array}{l}\text { Prehipertensi } \\
\text { (80-89 mmHg) }\end{array}$} & \multicolumn{2}{|c|}{$\begin{array}{c}\text { Hipertensi } \\
\text { Tahap } 1 \text { (90-99 } \\
\text { mmHg) }\end{array}$} & \multicolumn{2}{|c|}{$\begin{array}{c}\text { Hipertensi } \\
\text { Tahap } 2 \\
(\geq 100 \mathrm{mmHg})\end{array}$} & \multicolumn{2}{|c|}{ Total } \\
\hline & $\mathrm{N}$ & $\%$ & $\mathrm{~N}$ & $\%$ & $\mathrm{~N}$ & $\%$ & $\mathrm{~N}$ & $\%$ & $\mathrm{~N}$ & $\%$ \\
\hline Laki-laki & 0 & 0 & 7 & 36.8 & 2 & 33.3 & 1 & 33.3 & 10 & 33.3 \\
\hline Perempuan & 2 & 100 & 12 & 63.2 & 4 & 66.7 & 2 & 66.7 & 20 & 66.7 \\
\hline Total & 2 & 100 & 19 & 100 & 6 & 100 & 3 & 100 & 30 & 100 \\
\hline
\end{tabular}

Jenis kelamin perempuan lebih menderita hipertensi dari pada laki-laki. Terdapat $66.7 \%$ subjek berjenis kelamin perempuan yang tekanan darah diastoliknya berada pada hipertensi tahap 2 yaitu $\geq 100 \mathrm{mmHg}$. Dalam penelitian ini subjek yang banyak mengalami hipertensi adalah perempuan. Peningkatan tekanan darah sistolik dan diastolik dalam penelitian ini bisa terjadi karena adanya faktor lain seperti stress. Menurut penelitian yang dilakukan Lewa dkk (2010), lansia yang mengalami stress psikososial akan meningkatkan risiko terjadinya hipertensi sistolik terisolasi (HST) sebesar 2,54 kali lebih besar dibandingkan dengan lansia yang tidak mengalami stress psikososial [8].

Dari perhitungan dengan menggunakan uji statistik Pearson Chi Square yang diolah dengan menggunakan SPSS versi 17 didapatkan nilai signifikansi 0.776 yaitu $>0.05$ hal ini menunjukkan bahwa tidak ada hubungan antara jenis kelamin dengan tekanan darah diastolik. Sama seperti tekanan darah sistolik pada penelitian yang dilakukan oleh Novitaningtyas (2014), Novitaningtyas juga tidak menemukan adanya hubungan antara jenis kelamin dengan tekanan darah diastolik [5].

Tabel 6. Hubungan Usia Dengan Tekanan Darah Sistolik

Tekanan Darah Sistolik

\begin{tabular}{|c|c|c|c|c|c|c|c|c|c|}
\hline \multirow[t]{2}{*}{$\begin{array}{c}\text { Variabel } \\
\text { (Usia) }\end{array}$} & $\begin{array}{c}\text { Normal < } \\
120 \mathrm{mmHg}\end{array}$ & \multicolumn{2}{|c|}{$\begin{array}{c}\text { Prehipertensi } \\
(120-139 \\
\mathrm{mmHg})\end{array}$} & \multicolumn{2}{|c|}{$\begin{array}{c}\text { Hipertensi } \\
\text { Tahap } 1(140- \\
159 \mathrm{mmHg})\end{array}$} & \multicolumn{2}{|c|}{$\begin{array}{c}\text { Hipertensi } \\
\text { Tahap } 2 \\
(\geq 160 \mathrm{mmHg})\end{array}$} & \multicolumn{2}{|c|}{ Total } \\
\hline & $\%$ & $\mathrm{~N}$ & $\%$ & $\mathrm{~N}$ & $\%$ & $\mathrm{~N}$ & $\%$ & $\mathrm{~N}$ & $\%$ \\
\hline Dewasa Akhir & 20.0 & 1 & 7.7 & 0 & 0 & 0 & 0 & 2 & 6.7 \\
\hline
\end{tabular}


95 Ferry Effendi et al. (Hubungan Tingkat Kepatuhan Minum Obat...)

\begin{tabular}{lcccccccccc} 
Lansia Awal & 1 & 20.0 & 3 & 23.1 & 2 & 33.3 & 1 & 16.7 & 7 & 23.3 \\
Lansia Akhir & 1 & 20.0 & 7 & 53.8 & 2 & 33.3 & 2 & 33.3 & 12 & 40.0 \\
Manula & 2 & 40.0 & 2 & 15.4 & 2 & 33.3 & 3 & 50.0 & 9 & 30.0 \\
\hline Total & 5 & 100 & 13 & 100 & 6 & 100 & 6 & 100 & 30 & 100
\end{tabular}

Kelompok usia manula lebih meningkat tekanan darah sistoliknya. Terdapat 50.0\% kelompok usia manula yang tekanan darah sistoliknya berada pada hipertensi tahap 2 yaitu $\geq$ $160 \mathrm{mmHg}$. Hal ini sejalan dengan penelitian yang dilakukan oleh Novitaningtyas (2014) bahwa kelompok usia manula lebih besar mengalami peningkatan tekanan darah sistolik [5]. Mekanisme dasar terjadinya peningkatan tekanan darah sistolik berdasarkan usia yaitu penurunan elastisitas dan kemampuan meregang pada arteri besar. Tekanan aorta meningkat sangat tinggi dengan penambahan volume intravaskuler yang sedikit menunjukan kekakuan pembuluh darah pada usia lanjut [7].

Dari perhitungan dengan menggunakan uji statistik Pearson Chi Square yang diolah dengan menggunakan SPSS versi 17 didapatkan nilai signifikansi 0.768 yaitu $>0.05$ hal ini menunjukkan bahwa tidak ada hubungan antara usia dengan tekanan darah sistolik. Hal ini sejalan dengan penelitian yang dilakukan oleh Noviningtyas (2014), dalam penelitiannya Noviningtyas tidak menemukan adanya hubungan antara usia dengan tekanan darah sistolik [5].

Tabel 7. Hubungan Usia Dengan Tekanan Darah Diastolik

\begin{tabular}{|c|c|c|c|c|c|c|c|c|c|c|}
\hline \multirow{3}{*}{$\begin{array}{c}\text { Variabel } \\
\text { (Usia) }\end{array}$} & \multicolumn{8}{|c|}{ Tekanan Darah Diastolik } & & \\
\hline & \multicolumn{2}{|c|}{$\begin{array}{l}\text { Normal < } \\
80 \mathrm{mmHg}\end{array}$} & \multicolumn{2}{|c|}{$\begin{array}{l}\text { Prehipertensi } \\
(80-89 \mathrm{mmHg})\end{array}$} & \multicolumn{2}{|c|}{$\begin{array}{c}\text { Hipertensi } \\
\text { Tahap } 1 \text { (90- } \\
99 \text { mmHg) }\end{array}$} & \multicolumn{2}{|c|}{$\begin{array}{c}\text { Hipertensi } \\
\text { Tahap } 2 \\
(\geq 100 \mathrm{mmHg})\end{array}$} & \multicolumn{2}{|c|}{ Total } \\
\hline & $\mathrm{N}$ & $\%$ & $\mathrm{~N}$ & $\%$ & $\mathrm{~N}$ & $\%$ & $\mathrm{~N}$ & $\%$ & $\mathrm{~N}$ & $\%$ \\
\hline Dewasa Akhir & 0 & 0 & 2 & 10.5 & 0 & 0 & 0 & 0 & 2 & 6.7 \\
\hline Lansia Awal & 0 & 0 & 4 & 21.1 & 1 & 16.7 & 2 & 66.6 & 7 & $\begin{array}{c}23 . \\
3\end{array}$ \\
\hline Lansia Akhir & 1 & 50.0 & 9 & 47.4 & 2 & 33.3 & 0 & 0 & 12 & $\begin{array}{c}40 . \\
0\end{array}$ \\
\hline Manula & 1 & 50.0 & 4 & 21.1 & 3 & 50.0 & 1 & 33.3 & 9 & $\begin{array}{c}30 . \\
0\end{array}$ \\
\hline Total & 2 & 100 & 19 & 100 & 6 & 100 & 3 & 100 & 30 & $\begin{array}{c}10 \\
0\end{array}$ \\
\hline
\end{tabular}

Kelompok usia lansia awal lebih meningkat tekanan darah diastoliknya. Terdapat $66.6 \%$ kelompok usia lansia awal yang tekanan darah diastoliknya berada pada hipertensi tahap 2 yaitu $\geq 100 \mathrm{mmHg}$. Hal ini berbeda dengan penelitian yang dilakukan Novitaningtyas (2014) bahwa kelompok usia lansia tua lebih mengalami peningkatan tekanan darah diastolik [5].
Salah satu faktor peningkatan tekanan darah sistolik dan diastolik berdasarkan usia adalah asupan makan pada lansia. Berdasarkan penelitian yang dilakukan oleh Widyaningrum (2014) terdapat hubungan antara asupan natrium, kalium, dan magnesium dengan tekanan darah pada lansia di Kelurahan Makam haji [9]. Konsumsi natrium yang berlebihan menyebabkan 
konsentrasi natrium dalam cairan ekstraselular meningkat.

Meningkatnya cairan ekstraselular dalam tubuh menyebabkan meningkatnya volume darah dalam tubuh, dengan demikian jantung harus memompa lebih giat sehingga tekanan darah menjadi naik [10]. Asupan kalium juga mempengaruhi tekanan darah, kalium yang meningkat akan menurunkan tekanan darah sistolik dan diastolik [11]. Kadar kalium tinggi dapat meningkatkan ekskresi natrium, sehingga dapat menurunkan volume darah dan tekanan darah. Selain natrium dan kalium, magnesium juga memiliki peran penting dalam terjadinya kenaikan tekanan darah. Magnesium merupakan salah satu nutrien paling penting untuk kesehatan jantung yaitu membantu otot jantung untuk merelaksasi. Apabila kebutuhan magnesium tidak terpenuhi, akan terjadi penurunan tekanan darah sehingga akan terjadi detakan jantung yang tidak normal [12].

Dari perhitungan dengan menggunakan uji statistik Pearson Chi Square yang diolah dengan menggunakan SPSS versi 17 didapatkan nilai signifikansi 0.600 yaitu $>0.05$ hal ini menunjukkan bahwa tidak ada hubungan antara usia dengan tekanan darah diastolik. Hal ini sejalan dengan penelitian yang dilakukan oleh Noviningtyas (2014), dalam penelitiannya Noviningtyas juga tidak menemukan adanya hubungan antara usia dengan tekanan darah diastolik sama seperti hubungan antara usia dengan tekanan darah sistolik sebelumnya [5].

Tabel 8. Hubungan Pendidikan Dengan Tekanan Darah Sistolik

\begin{tabular}{|c|c|c|c|c|c|c|c|c|c|c|}
\hline \multirow{3}{*}{$\begin{array}{c}\text { Variabel } \\
\text { (Pendidikan) }\end{array}$} & \multicolumn{8}{|c|}{ Tekanan Darah Sistolik } & & \\
\hline & \multicolumn{2}{|c|}{$\begin{array}{c}\text { Normal < } \\
120 \mathrm{mmHg}\end{array}$} & \multicolumn{2}{|c|}{$\begin{array}{c}\text { Prehipertensi } \\
(120-139 \\
\mathrm{mmHg})\end{array}$} & \multicolumn{2}{|c|}{$\begin{array}{c}\text { Hipertensi } \\
\text { Tahap } 1(140- \\
159 \mathrm{mmHg})\end{array}$} & \multicolumn{2}{|c|}{$\begin{array}{l}\text { Hipertensi } \\
\text { Tahap } 2 \\
(\geq 160 \mathrm{mmHg})\end{array}$} & \multicolumn{2}{|c|}{ Total } \\
\hline & $\mathrm{N}$ & $\%$ & $\mathrm{~N}$ & $\%$ & $\mathrm{~N}$ & $\%$ & $\mathrm{~N}$ & $\%$ & $\mathrm{~N}$ & $\%$ \\
\hline SD & 1 & 20.0 & 1 & 7.7 & 1 & 16.7 & 1 & 16.7 & 4 & 13.3 \\
\hline SMP & 0 & 0 & 0 & 0 & 1 & 16.7 & 2 & 33.3 & 3 & 10.0 \\
\hline SMA & 1 & 20.0 & 8 & 61.5 & 3 & 50.0 & 3 & 50.0 & 15 & 50.0 \\
\hline D3 & 1 & 20.0 & 2 & 15.4 & 0 & 0 & 0 & 0 & 3 & 10.0 \\
\hline S1 & 1 & 20.0 & 1 & 7.7 & 1 & 16.7 & 0 & 0 & 3 & 10.0 \\
\hline S2 & 1 & 20.0 & 1 & 7.7 & 0 & 0 & 0 & 0 & 2 & 6.7 \\
\hline Total & 5 & 100 & 13 & 100 & 6 & 100 & 6 & 100 & 30 & 100 \\
\hline \multicolumn{5}{|c|}{$\begin{array}{l}\text { Kenaikan tekanan darah sistolik cenderung } \\
\text { erjadi pada tingkat pendidikan SMA. Terdapat } \\
50.0 \% \text { kelompok pendidikan SMA yang tekanan } \\
\text { darah sistoliknya berada pada hipertensi tahap } 2 \\
\text { yaitu } \geq 160 \text { mmHg. Responden dengan } \\
\text { pendidikan tinggi tekanan darah sistoliknya } \\
\text { cenderung normal. Hal ini berbeda dengan } \\
\text { penelitian yang dilakukan oleh Tri N (2014) } \\
\text { bahwa hipertensi cenderung terjadi pada } \\
\text { seseorang yang tingkat pendidikannya masih } \\
\text { dalam katagori SD. }\end{array}$} & \multicolumn{6}{|c|}{$\begin{array}{l}\text { Dari perhitungan dengan menggunakan uji } \\
\text { istik Pearson Chi Square yang diolah dengan } \\
\text { nggunakan SPSS versi } 17 \text { didapatkan nilai } \\
\text { nifikansi 0.616 yaitu > } 0.05 \text { hal ini } \\
\text { nunjukkan bahwa tidak ada hubungan antara } \\
\text { didikan dengan tekanan darah sistolik. Hal ini } \\
\text { alan dengan penelitian yang dilakukkan } \\
\text { gan Novitaningtyas (2014), bahwa dalam } \\
\text { elitiannya Novitaningtyas tidak menemukkan } \\
\text { nya hubungan antara pendidikan dengan } \\
\text { anan darah sistolik [5]. }\end{array}$} \\
\hline
\end{tabular}

Tabel 9. Hubungan Pendidikan Dengan Tekanan Darah Diastolik 


\begin{tabular}{|c|c|c|c|c|c|c|c|c|c|c|}
\hline \multirow{3}{*}{$\begin{array}{c}\text { Variabel } \\
\text { (Pendidikan) }\end{array}$} & \multicolumn{8}{|c|}{ Tekanan Darah Diastolik } & & \\
\hline & \multicolumn{2}{|c|}{$\begin{array}{l}\text { Normal < } \\
80 \mathrm{mmHg}\end{array}$} & \multicolumn{2}{|c|}{$\begin{array}{l}\text { Prehipertensi } \\
(80-89 \mathrm{mmHg})\end{array}$} & \multicolumn{2}{|c|}{$\begin{array}{c}\text { Hipertensi } \\
\text { Tahap } 1 \text { (90-99 } \\
\text { mmHg) }\end{array}$} & \multicolumn{2}{|c|}{$\begin{array}{c}\text { Hipertensi } \\
\text { Tahap } 2 \\
(\geq 100 \mathrm{mmHg})\end{array}$} & \multicolumn{2}{|c|}{ Total } \\
\hline & $\mathrm{N}$ & $\%$ & $\mathrm{~N}$ & $\%$ & $\mathrm{~N}$ & $\%$ & $\mathrm{~N}$ & $\%$ & $\mathrm{~N}$ & $\%$ \\
\hline SD & 0 & 0 & 3 & 15.8 & 0 & 0 & 1 & 33.3 & 4 & 13.3 \\
\hline SMP & 0 & 0 & 1 & 5.3 & 2 & 33.3 & 0 & 0 & 3 & 10.0 \\
\hline SMA & 2 & 100 & 8 & 42.1 & 3 & 50.0 & 2 & 66.7 & 15 & 50.0 \\
\hline D3 & 0 & 0 & 3 & 15.8 & 0 & 0 & 0 & 0 & 3 & 10.0 \\
\hline S1 & 0 & 0 & 2 & 10.5 & 1 & 16.7 & 0 & 0 & 3 & 10.0 \\
\hline S2 & 0 & 0 & 2 & 10.5 & 0 & 0 & 0 & 0 & 2 & 6.7 \\
\hline Total & 2 & 100 & 19 & 100 & 6 & 100 & 3 & 100 & 30 & 100 \\
\hline
\end{tabular}

Kenaikan tekanan darah diastolik lebih banyak terjadi pada tingkat pendidikan SMA sama halnya dengan kenaikan tekanan darah sistolik. Terdapat $66.7 \%$ kelompok pendidikan SMA yang tekanan darah sistoliknya berada pada hipertensi tahap 2 yaitu $\geq 160 \mathrm{mmHg}$. Tingkat pendidikan secara tidak langsung mempengaruhi tekanan darah pada lansia karena tingkat pendidikan berpengaruh terhadap gaya hidup seseorang yaitu seperti kebiasaan merokok, kebiasaan mengkonsumsi alkohol, asupan makanan, dan aktivitas fisik [13].

Dalam penelitian yang dilakukan oleh Novitaningtyas (2014) terdapat 37.5\% subyek berjenis kelamin laki-laki dengan katagori tingkat pendidikan SD memiliki kebiasaan merokok dan mengalami hipertensi [5]. Menurut penelitian yang dilakukan oleh Lewa dkk (2010) lansia yang memiliki kebiasaan merokok akan meningkatkan risiko kejadian Hipertensi Sistolik Terisolasi (HST) sebesar 2,803 kali lebih besar dibandingkan lansia yang tidak merokok [6].
Kebiasaan merokok bisa meningkatkan tekanan darah tinggi atau hipertensi karena nikotin yang terkandung didalam rokok bisa mengakibatkan pengapuran dinding pembuluh darah [7]. Nikotin dan karbondioksida yang terkandung dalam rokok akan merusak lapisan endotel pembuluh darah arteri, elastisitas pembuluh darah berkurang sehingga pembuluh darah menjadi kaku dan menganggu aliran darah sehingga menyebabkan tekanan darah meningkat [13].

Dari perhitungan dengan menggunakan uji statistik Pearson Chi Square yang diolah dengan menggunakan SPSS versi 17 didapatkan nilai signifikansi 0.730 yaitu $>0.05$ hal ini menunjukkan bahwa tidak ada hubungan antara pendidikan dengan tekanan darah diastolik. Hal ini sejalan dengan penelitian yang dilakukan oleh Novitaningtyas (2014), bahwa dalam penelitiannya Novitaningtyas tidak menemukan adanya hubungan antara pendidikan dengan tekanan darah diastolik sama seperti tekanan darah sistolik sebelumnya [5]. 
Tabel 10. Hubungan Kepatuhan Dengan Tekanan Darah Sistolik

\begin{tabular}{|c|c|c|c|c|c|c|c|c|c|c|}
\hline \multirow{3}{*}{$\begin{array}{c}\text { Variabel } \\
\text { (Kepatuhan) }\end{array}$} & \multicolumn{8}{|c|}{ Tekanan Darah Sistolik } & & \\
\hline & \multicolumn{2}{|c|}{$\begin{array}{c}\text { Normal < } \\
120 \mathrm{mmHg}\end{array}$} & \multicolumn{2}{|c|}{$\begin{array}{c}\text { Prehipertensi } \\
(120-139 \\
\mathrm{mmHg})\end{array}$} & \multicolumn{2}{|c|}{$\begin{array}{c}\text { Hipertensi } \\
\text { Tahap } 1(140- \\
159 \mathrm{mmHg})\end{array}$} & \multicolumn{2}{|c|}{$\begin{array}{c}\text { Hipertensi } \\
\text { Tahap } 2 \\
(\geq 160 \mathrm{mmHg})\end{array}$} & \multicolumn{2}{|c|}{ Total } \\
\hline & $\mathrm{N}$ & $\%$ & $\mathrm{~N}$ & $\%$ & $\mathrm{~N}$ & $\%$ & $\mathrm{~N}$ & $\%$ & $\mathrm{~N}$ & $\%$ \\
\hline $\begin{array}{l}\text { Kepatuhan } \\
\text { Tinggi }\end{array}$ & 5 & 100 & 4 & 30.8 & 4 & 66.7 & 1 & 16.7 & 14 & 46.7 \\
\hline $\begin{array}{l}\text { Kepatuhan } \\
\text { Sedang }\end{array}$ & 0 & 0 & 4 & 30.8 & 0 & 0 & 1 & 16.7 & 5 & 16.7 \\
\hline $\begin{array}{l}\text { Kepatuhan } \\
\text { Rendah }\end{array}$ & 0 & 0 & 5 & 38.5 & 2 & 33.3 & 4 & 66.7 & 11 & 36.7 \\
\hline Total & 5 & 100 & 13 & 100 & 6 & 100 & 6 & 100 & 30 & 100 \\
\hline
\end{tabular}

Responden dengan kepatuhan tinggi tekanan darah diastoliknya lebih normal dibandingkan dengan kepatuhan sedang dan rendah. Dan pada responden dengan kepatuhan rendah tekanan darahnya lebih meningkat. Terdapat $66.7 \%$ responden dengan kepatuhan rendah yang tekanan darahnya berada pada hipertensi tahap 2 yaitu $\geq 160 \mathrm{mmHg}$. Dari perhitungan dengan menggunakan uji statistik Pearson Chi Square yang diolah dengan menggunakan SPSS versi 17 didapatkan nilai signifikansi 0.059 yaitu $>0.05$ hal ini menunjukkan bahwa tidak ada hubungan antara kepatuhan dengan tekanan darah sistolik. Kemudian dilakukan uji lanjutan untuk mengetahui kekuatan hubungan kepatuhan minum obat dengan tekanan darah sistolik dilakukan uji korelasi Spearman rho's.

Dari hasil uji normalitas kolmogrov smirnov menunjukan hasil tidak terdistribusi secara normal. Dalam penelitian ini data yang digunakan tidak terdistribusi secara normal karena adanya keterbatasan pengambilan sampel penelitian. Hasil uji korelasi antara kepatuhan minum obat dengan tekanan darah sistolik menggunakan uji korelasi Spearman rho's memperoleh nilai $\mathrm{p}$ signifikansi sebesar 0.038 yaitu $<0,05$, maka $\mathrm{H} 0$ ditolak dan H1 diterima sehingga terdapat hubungan antara tingkat kepatuhan minum obat dengan tekanan darah sistolik. Dengan nilai koefisien korelasi sebesar $0,380 *$ yang artinya kekuatan hubungan cukup atau lemah.

Dalam penelitian ini didapatkan hasil kekuatan hubungan cukup, dapat dikarenakan bahwa masih terdapat responden dengan kepatuhan tinggi tetapi tekanan darah nya masuk kedalam katagori hipertensi tahap I maupun hipertensi tahap II. Peneliti menduga bahwa hal ini terjadi karena adanya faktor lain yang menyebabkan tekanan darah nya meningkat walaupun sudah patuh meminum obat, seperti asupan makan yang dikonsumsi oleh responden. Penelitian ini sejalan dengan penelitian yang dilakukan oleh (Awali, 2016) dalam penelitiannya Awali juga menemukan adanya hubungan kepatuhan minum obat dengan tekanan darah sistolik [14]. 
Tabel 11. Hubungan Kepatuhan Dengan Tekanan Darah Diastolik

\begin{tabular}{|c|c|c|c|c|c|c|c|c|c|c|}
\hline \multirow{3}{*}{$\begin{array}{c}\text { Variabel } \\
\text { (Kepatuhan) }\end{array}$} & \multicolumn{8}{|c|}{ Tekanan Darah Diastolik } & & \\
\hline & \multicolumn{2}{|c|}{$\begin{array}{l}\text { Normal < } \\
80 \mathrm{mmHg}\end{array}$} & \multicolumn{2}{|c|}{$\begin{array}{l}\text { Prehipertensi } \\
(80-89 \mathrm{mmHg})\end{array}$} & \multicolumn{2}{|c|}{$\begin{array}{c}\text { Hipertensi } \\
\text { Tahap } 1 \text { (90-99 } \\
\text { mmHg) }\end{array}$} & \multicolumn{2}{|c|}{$\begin{array}{c}\text { Hipertensi } \\
\text { Tahap } 2 \\
(\geq 100 \mathrm{mmHg})\end{array}$} & \multicolumn{2}{|c|}{ Total } \\
\hline & $\mathrm{N}$ & $\%$ & $\mathrm{~N}$ & $\%$ & $\mathrm{~N}$ & $\%$ & $\mathrm{~N}$ & $\%$ & $\mathrm{~N}$ & $\%$ \\
\hline $\begin{array}{l}\text { Kepatuhan } \\
\text { Tinggi }\end{array}$ & 2 & 100 & 8 & 42.1 & 2 & 33.3 & 2 & 66.7 & 14 & 46.7 \\
\hline $\begin{array}{l}\text { Kepatuhan } \\
\text { Sedang }\end{array}$ & 0 & 0 & 5 & 26.3 & 0 & 0 & 0 & 0 & 5 & 16.7 \\
\hline $\begin{array}{l}\text { Kepatuhan } \\
\text { Rendah }\end{array}$ & 0 & 0 & 6 & 31.6 & 4 & 66.7 & 1 & 33.3 & 11 & 36.7 \\
\hline Total & 2 & 100 & 19 & 100 & 6 & 100 & 3 & 100 & 30 & 100 \\
\hline
\end{tabular}

Responden dengan kepatuhan tinggi tekanan darah diastoliknya lebih normal dibandingkan dengan kepatuhan sedang dan rendah sama halnya dengan peningkatan tekanan darah sistolik sebelumnya. Terdapat $66.7 \%$ responden dengan kepatuhan rendah yang tekanan darah diastoliknya berada pada hipertensi tahap 1 yaitu 90-99 $\mathrm{mmHg}$.

Dari perhitungan dengan menggunakan uji statistik Pearson Chi Square yang diolah dengan menggunakan SPSS versi 17 didapatkan nilai signifikansi 0.318 yaitu $>0.05$ hal ini menunjukkan bahwa tidak ada hubungan antara kepatuhan dengan tekanan darah diastolik. Kemudian dilakukan uji lanjutan untuk mengetahui kekuatan hubungan kepatuhan minum obat dengan tekanan darah diastolik dilakukan uji korelasi Spearman rho's.

Dari hasil uji normalitas kolmogrov smirnov menunjukan hasil tidak terdistribusi secara normal. Dalam penelitian ini data yang digunakan tidak terdistribusi secara normal karena adanya keterbatasan pengambilan sampel penelitian. Hasil uji korelasi antara kepatuhan minum obat dengan tekanan darah sistolik menggunakan uji korelasi Spearman rho's diperoleh nilai $\mathrm{p}$ signifikansi sebesar 0.024 yaitu $<0,05$, maka H0 ditolak dan $\mathrm{H} 1$ diterima sehingga terdapat hubungan antara tingkat kepatuhan minum obat dengan tekanan darah diastolik.

Dengan nilai koefisien korelasi sebesar $0,411^{*}$ yang artinya kekuatan hubungan cukup. Dalam penelitian ini didapatkan hasil kekuatan hubungan cukup, dapat dikarenakan bahwa masih terdapat responden dengan kepatuhan tinggi tetapi tekanan darah nya masuk kedalam katagori hipertensi tahap I maupun hipertensi tahap II.
Peneliti menduga bahwa hal ini terjadi karena adanya faktor lain yang menyebabkan tekanan darah nya meningkat walaupun sudah patuh meminum obat, seperti gaya hidup dan tingkat stress responden.

Penelitian ini sejalan dengan penelitian yang dilakukan oleh (Awali, 2016) dalam penelitiannya Awali menemukan adanya hubungan kepatuhan minum obat dengan tekanan darah diastolic [14]. Hipertensi adalah penyakit yang tidak dapat disembuhkan tetapi dapat dikendalikan atau dikontrol dengan cara mengkonsumsi obat antihipertensi seumur hidup. Patuh minum obat pada penyakit hipertensi merupakan hal yang sangat penting karena dengan meninum obat antihipertensi secara teratur dapat mengendalikan atau mengkontrol tekanan darah penderita hipertensi.

Tekanan darah yang terkendali akan menurunkan risiko kejadian kardiovaskular. Faktor-faktor lain yang mempengaruhi tingkat kepatuhan minum obat pada pasien hipertensi yang tidak diteliti pada penelitian ini antara lain: modifikasi faktor lingkungan dan sosial, perubahan model terapi, interaksi profesional, faktor sistem kesehatan, faktor kondisi, faktor terapi dan faktor klien juga mempengaruhi kepatuhan.

\section{SIMPULAN}

Pada penelitian ini dapat disimpulkan bahwa terdapat hubungan antara tingkat kepatuhan minum obat dengan tekanan darah sistolik di Kelompok Prolanis Klinik Qita dengan hasil $\mathrm{p}$ value $=0,038$ yaitu $<0,05$ dengan kekuatan hubungan cukup, dan juga terdapat hubungan antara tingkat kepatuhan minum obat dengan tekanan darah diastolik di Kelompok Prolanis 
Klinik Qita dengan hasil p value $=0,024$ yaitu < 0,05 dengan kekuatan hubungan cukup.

\section{DAFTAR PUSTAKA}

[1] Morisky DE, Ang A, Krousel-wood M, Ward HJ. 2007. Predictive Validity of a Medication Adherence Measure in an Outpatient Setting. The Journal of Clinical Hypertension. 10: 348-354.

[2] Muhadi, et al. 2014. Panduan Klinis PROLANIS Hipertensi BPJS Kesehatan. Jakarta: Badan Penyelenggara Jaminan Sosial: 5, 14-32, 45-48.

[3] Dudella, Yasin, et al. 2012. Analisis Faktor-Faktor Yang Berhubungan Dengan Kepatuhan Minum Obat Pada Pasien Hipertensi Di Poliklinik Jantung Rumah Sakit Umum Daerah Dr. Saiful Anwar Malang. Malang. Majalah Kesehatan Fakultas Kedokteran Universitas Brawijaya: 7.

[4] Kanda, Halbar A. 2014. Hubungan Tingkat Kepatuhan Minum Obat Dengan Kestabilan Tekanan Darah Pada Pasien Hipertensi di Poli Jantung Rumah Sakit Umum Daerah Zainoel Abidin 2014. Banda Aceh: Program Studi Pendidikan Dokter Fakultas Kedokteran Universitas Syiah Kuala Darussalam: 5-7, 13-14, 1823.

[5] Novitaningtyas, Tri. 2014. Hubungan Karakteristik (Umur, Jenis Kelamin, Tingkat Pendidikan) Dan Aktivitas Fisik Dengan Tekanan Darah Pada Lansia Di Kelurahan Makamhaji Kecamatan Kartasura Kabupaten Sukoharjo. Surakarta: Program Studi Gizi Fakultas Ilmu Kesehatan Universitas Muhammadiyah Surakarta: 5-9.

[6] Lewa, et al. 2010. Faktor-faktor Risiko Hipertensi Sistolik Terisolasi Pada Lanjut
Usia. Berita Kedokteran Masyarakat. 26 (4): 171-178.

[7] Singalingging, G. 2011. Karakteristik Penderita Hipertensi Di Rumah Sakit Umum Herna Medan 2011. Medan: 1-6.

[8] Rahmawati, Sari. 2013. Hubungan Antara Derajat Hipertensi Pada Pasien Usia Lanjut Dengan Komplikasi Organ Target Di RSUP Dokter Kariadi Semarang Periode 2008-2012. Semarang: Fakultas Kedokteran Universitas Diponogoro: 19.

[9] Widyaningrum. 2014. Hubungan Asupan Natrium, Kalium, Magnesium Dan Status Gizi Dengan Tekanan Darah Pada Lansia Di Kelurahan Makamhaji Kartasura. Surakarta: Program Studi Ilmu Gizi Fakultas Ilmu Kesehatan Universitan Muhammadiyah Surakarta.

[10] Dalimartha. 2008. Care Your Self Hypertension. Penebar Plus: Jakarta.

[11] Brunner and Suddarth. 2001. Keperawatan Medikal Bedah (8). Jakarta: EGC.

[12] Andarini. 2012. Terapi Nutrisi Pasien Usia Lanjut yang Dirawat di RS Dalam. Jakarta: Departemen Ilmu Penyakit Dalam Fakultas Kedokteran UI.

[13] Anggara dan Prayitno. 2013. Faktor-Faktor Yang Berhubungan Dengan Tekanan Darah Di Puskesmas Telaga Murni, Cikarang Barat Tahun 2012. Jakarta: Program Studi S1 Kesehatan Masyarakat Sekolah Tinggi Ilmu Kesehatan MH. Thamrin.

[14] Awali, Sholehah. 2016. Hubungan Minum Obat Antihipertensi Terhadap Tekanan Darah Pasien Hipertensi Di Desa Salamrejo. Yogyakarta: Program Studi Ilmu Keperawatan Fakultas Kedokteran Dan Ilmu Kesehatan Universitas Muhamadiyah Yogyakarta: 14-15. 